\title{
Preparación de alumnos de licenciatura para el éxito en su carrera profesional a través de la elaboración e implementación de estudios de caso en contextos reales de trabajo \\ Preparing undergraduate students for career success through case study writing and implementation in real job contexts
}

Francisco Gerardo Barroso Tanoira ${ }^{1}$

Palabras Clave: casos de estudio; casos; procesos de aprendizaje; gestión del conocimiento; éxito profesional

\section{Recepción: 18-05-2017 / Aceptación: 25-08-2017}

\section{Resumen}

El objetivo de esta investigación fue probar la eficacia de un procedimiento para enseñar a estudiantes de licenciatura a escribir e implementar casos de estudio para mejorar sus experiencias de aprendizaje, adaptarse más rápidamente al medio laboral y estar mejor preparados para el éxito en su carrera profesional.

\section{Método}

Estudiantes universitarios que realizan su servicio social en la Auditoría Superior de los estados de Yucatán, Campeche y Q. Roo, en el Sureste de México, bajo la guía de auditores gubernamentales, diseñaron casos para implementar a sus compañeros de escuela siguiendo el procedimiento estudiado en este documento, preparado por el autor de esta investigación.

\section{Resultados}

Los resultados mostraron que, después de esta experiencia, los estudiantes estuvieron más motivados para aprender, más interesados en casos de estudio, sintieron más confianza al trabajar con otros y estuvieron más satisfechos con el aprendizaje, en comparación con los métodos tradicionales de enseñanza, según su percepción.

\section{Conclusión}

Este procedimiento para casos de estudio es eficaz para preparar a los estudiantes para mejorar sus competencias técnicas y socioemocionales en preparación para su éxito profesional, pero también

${ }^{1}$ Facultad de Economía y Negocios, Universidad Anáhuac Mayab. Mérida, Yucatán. E-mail: francisco.barroso@anahuac.mx

(C) Universidad De La Salle Bajío (México) 
fue una oportunidad de desarrollo profesional para los auditores. Aprender a escribir y a implementar casos facilita el aprendizaje y la adaptación al medio laboral. Es aprender a aprender y prepararse para el éxito profesional a través de experiencias como ésta en contextos reales de trabajo.

\section{Abstract}

The objective of this study was to test the effectiveness of a procedure to train undergraduate students to write and implement case studies for improving their learning experiences, adapt to the labor environment and be better prepared for career success.

\section{Method}

Undergraduate students in social service internships at the Higher State Auditing Office in the states of Yucatan, Campeche and Q. Roo, in the Southeast of Mexico, under the guidance of Government Auditors, designed case studies to be implemented with their classmates following the procedure studied in this document, prepared by the author of this research.

\section{Results}

Results showed that after this experience, implementer students were more motivated for learning, more interested in case studies, more confident at working with others and were satisfied with learning. This was compared to the learning through traditional methods, according to their perception.

\section{Conclusion}

This case study procedure is effective for preparing students for improving their technical and socio-emotional competencies in their preparation for career success, but also a professional development opportunity for the Auditors. Learning to write and implement cases help learning and adaptation to work environment. It is learning how to learn and be prepared for career success through experiences such as this in real job contexts.

Keywords: case studies; cases; learning processes; knowledge management; professional success. 


\section{Introduction}

Traditional education has reinforced memory and competition considering school as a preparation for life instead as part of life (Peters, 2012), motivating the student for achieving a high score. However, it seems that getting the maximum score ("A+", 10 or 100, depending on the scale) does not motivate the student to learn more... it only motivates him to continue achieving such scores (in this document, "he" and "him" also refer to "she" and "her" respectively). According to Robinson (2010), the most comparable place to a factory is a school. This is due to the fact that in both organizations there are ring bells for setting times, labor division, departments and standards. In traditional school systems, too many students are placed in the same classroom, where the professor teaches and applies statistics to check who passes or fails. Students usually pass and it seems that it's acceptable to have some of them failing if the number is not statistically "significant". Is it all right to consider students under quality control as if they were products? The obvious answer is "no".

On the other hand, there are the constructivist methods in which students must be the managers of their own knowledge. The school is a part of life and the program is determined by the mission, philosophy and goals in a challenging, funny and interesting way (Peters, 2012). Since success is determined through collaboration while intelligence is measured in real life problem solving, the professor is seen as a guide who fosters thinking instead of a judge passing sentence or a quality control supervisor. Therefore, the student is acknowledged as the most important person in the process. Instead of teaching the student, the objective must be helping him to learn what he needs for future performance, for which it is important to create the conditions in class to allow him to take an active role in his own learning. This means that the teacher must work out of the class and prepare the materials and activities to make the student get involved in his own learning. Then, we can say that the best teacher is not the one with the best answers, but that with the best questions and leadership to help the student become engaged with his own learning.

For Robinson (2010), we are trying to prepare the students for the world they will face in five years, even when we don't know how the environment will be like the following weekend. Besides, education is not transferring knowledge from a full head (the teacher's) to an empty one (the student's). It is helping the student to be what he was born for, which means an effort for constant exploration, discovery, learning and experimenting, acquiring the competencies for joining the labor market and getting a job upon graduation. It is also helping students to be critical,

No 19, Vol. 9 (2), 2017. ISSN 2007 - 0705, pp.: 568 - 594 
use systemic thinking and learn how to learn (Barroso, 2010). If they do that, they will certainly have more opportunities to adapt to their labor environment effectively, despite the uncertainty in the environment.

The most important goal of the school system must be preparing students for career success, focusing on what they need and not in what the school (or the teacher) just thinks they will need. For achieving this and beyond certification efforts, schools and teachers must learn how to learn and replace bureaucratic protocols with the design of effective learning strategies (Sveivy, 2001). I'm glad there are business firms doing this with their staff: changing the training focus from "teaching needs" to "learning needs", centering in the apprentice (the employee) and designing programs for helping those workers to learn through a process. This process includes exploration, discovery, experimenting and learning...yes, the same as at school. Companies enhancing creative and critical thinking for solving problems are innovation oriented and more profitable, increasing employee satisfaction and reducing turnover and absenteeism (Barroso, 2010). People become more motivated when they feel productive and realize they're learning, so they are challenged to improve. It is important to say that this is only possible if leadership is participative and enhances a good labor environment.

\section{Problem statement}

There are students who think that what they learn at school will only be the necessary to pass exams, and that the real career will be learned once they are in the outside world after graduation. Therefore, it appears that there's a difference between academic and work learning as if they were two different worlds. If attending school and studying boring and useless material is the necessary to obtain a professional position in a firm, then this is why some students could feel unmotivated and willing to drop out. So, why not connect the academic experience with the real world in a way in which students feel that there is an academy-work link? It is providing students with as many experiences as they will get outside, for which writing case studies are a good way to do so (Ellet, 2007). Student written cases are powerful pedagogical tools because they help students improve their understanding of business situations, there is more informed analysis, there are more opportunities for reflection and the opportunity for improving oral and written communication skills (Vega, 2009), losing fear to share and support their arguments. For showing the importance 
of case studies, a research experience in the Southeast of Mexico will be presented and discussed in this document.

Government Auditors from the states of Yucatan, Campeche and Quintana Roo, in the Southeast of Mexico, reported that although their assistants - university students in a professional practice internship- have studied Auditing at their schools and some of them have received good grades, those students are not always motivated or they lack some important knowledge about the Auditing field work, information handling and evidence gathering for Government Auditors to render a verdict and prepare final audit reports. This is expensive and ineffective because the students stay at the Government Auditing Department (GAD) just for a semester and once they have learned the Auditing procedures, the semester is over and the Auditors have to train new students for the following semester. This cycle continues permanently, it's not cost-benefit effective and students do not become motivated to become Auditors. Finally, it becomes just an experience for completing the professional practices and that's all. Auditors need a better and faster way for training the students they will be working with.

A good way for teaching students is helping them discover, explore and experiment in real work contexts. More than just teaching, it is helping them learn how to learn and get engaged with their own learning, giving full meaning to what they do in the process. For this, Auditors must be able to detect problems and teach their staff how to solve them, and a good way for doing so could be solving and writing case studies because higher learning levels are involved (Peters, 2012) and the students could adapt to their work faster. This way they connect to real work situations and get motivated to research, solve problems and create value for their organizations. If solving cases helps, writing them is a more powerful tool for students to learn (Vega, 2009). However, the real challenge for those students is to be able to write and implement such cases. A consistent procedure for training students to do so could be very helpful for the GAD and any other organization.

\section{Objective}

The objective of this study was to test the effectiveness of a procedure to train students to write and implement case studies for a more significant learning and faster adaptation to work, as part of their preparation for career success.

No 19, Vol. 9 (2), 2017. ISSN 2007 - 0705, pp.: 568 - 594 


\section{Benefits of the study}

Case studies are good for students to think, explore, discover and experiment in a funny and meaningful way (Ellet, 2007), especially when they design and implement those cases (Gin, 2009). This practice is desired in real work situations, especially when the student becomes a leader and has subordinates to train. Case studies do not have a unique answer, so the best cases are those which enhance discussion, analysis, synthesis and learning. This experience is easy to replicate and effective.

A person is more valuable in an organization because of two important qualities: (1) being capable to learn, and (2) being willing to learn (Barroso, 2010). The writing and implementation of case studies could be good for business firms and other organizations for motivating their employees through more meaningful, faster and effective training, as well as fostering a better and quicker adaptation to work. Besides, cases could be used in undergraduate and graduate levels.

\section{Limitations}

The results are only valid for the study context, but the methodology could be replicated in other situations with the corresponding changes. The Auditors and students participating are from the states of Yucatan (the capital city is Mérida), Campeche (the capital is Campeche) and Quintana Roo (the capital is Chetumal), in the Southeast of Mexico. The Auditors were studying a Master's Degree in Auditing at the Anahuac Mayab University and working at the Governmental Audit Department (GAD) in the three states. The undergraduate students were in the professional practices internship (mandatory at every higher education institution in Mexico), working under the supervision of those Auditors at the GADs. The study was conducted from July 2015 to June 2016, during the Case Study course in the Master's Degree program in Auditing in the three cities, in which Auditors learned how to analyze and solve case studies.

\section{Literature Review}

\section{Importance of a constructivist environment}

The lecture method is good for transmitting information. However, in a constructivist method as the case studies, students receive knowledge from an expert (Peters, 2012) and create knowledge 
with the help of an expert (Ellet, 2007). This fundamental change causes confusion in many new students because they are used to memorizing, not learning how to learn.

In business and in the knowledge economy today, it is important that employees think by themselves (Barroso, 2010). The ability for thinking clearly and communicating persuasively have always been important for managers and leaders (Aceves \& Barroso, 2016). Then, a well written document could have an interior source of competitive advantage (Ellet, 2007).

For improving learning, it is necessary to build a student centered environment, for which Brent (1996) suggests that the teachers must foster a correct environment to include proper support and guidance, as well as rich resources and tools. Then, a constructivist learning environment is "a place where participants may work together and support one another through the use of a variety of tools and information resources in their guided pursuit of learning goals and problem-solving activities" (p. 5). For Honebein (1996), there are seven goals for designing a learning environment:

1) Provide experience with the knowledge-construction environment. It means that the teacher's role is to facilitate the learning process as a guide, but that process must be student centered.

2) Provide experience and appreciation for multiple perspectives. The teacher must enable the students to evaluate alternative solutions to problems for testing and enriching what they have understood.

3) Embed learning in realistic and relevant contexts. That is a problem with traditional teaching-centered education techniques because problems in textbooks are good for classes, but they are not necessarily connected to the students' life.

4) Encourage ownership and voice in the learning process. The teacher is a consultant, so the students must assume their role in solving problems, designing projects or other learning activities.

5) Embed learning in social experience. The learning process must enhance teacherstudent collaboration, but also student-student cooperation.

6) Encourage the use of multiple modes of representation. Enhance the use of graphs, charts, video, computers, photographs, sound and others.

7) Encourage self-awareness to the knowledge constructions process. It's important to enhance reflexivity aimed to have metacognition (Flavell, 1978), this is, that the 
student reflects on information, experiences and old knowledge to create new knowledge.

The learning environment to be constructed must consider the teacher as a guide and facilitator (Peters, 2012). The community must be an extension of the classroom and the decisions must be shared with the student participating teams, allowing learning to be in a spiral instead of the traditional linear way. In a constructivist environment, knowledge is constructed through playing, direct experience and social interaction, integrating disciplines and making connections instead of the traditional learning through lectures, worksheets and texts. All of this makes the case study method the ideal for achieving competencies through a person centered focus (Ellet, 2007; Vega, 2009), integrating previous knowledge and experiences in a team oriented work which, according to Giménez (2012), is based on real life.

\section{Building intangible assets}

For Kaplan \& Norton (1996), intangible assets help companies: (a) develop relations with customers for creating and keeping their loyalty: (b) attract new markets and give them a service with more quality and efficacy; (c) introduce innovative products and services for meeting market needs; (d) develop new and personalized products and services with high quality, low costs and optimum time; (e) develop in employees the best practices for achieving quality and faster response times, and (f) with information technology create data bases and systems. For achieving this, Sveiby (2001) comments that employees, regardless hierarchies, have to work in two ways: (1) inside the company, building the internal structure, and (2) outside, working with customers, suppliers and other organizations. Then, employees must be competent at performing well in different situations and create value, for which five factors are needed:

1) Explicit knowledge. This is formal education, degrees, certifications.

2) Practice. It is knowing how to do things, so training and practice are required.

3) Experience. Knowledge acquired through the practice.

4) Values. Convictions and beliefs about what is correct.

5) Social nets. Relations with other individuals inside an environment and culture. 
Besides, workers must be able to contribute to the internal structure, which includes creating patents, concepts, models and information systems (Barroso \& Córdova, 2013). They are expected to build a good relationship with customers and suppliers.

\section{Competencies}

A competency is an everyday more frequently mentioned concept in companies because of the need of improving talent development. McClelland, quoted by Robbins \& Judge (2013), defined this term as the subjacent features in a person that are cause-effect related with behavior and successful actions in his professional activity. For that author, subjacent features are all aspects a person gives the organization (company or any other), which is the sum of his cognitive capabilities (aptitudes); behavior tendencies (attitudes) and knowledge acquired.

\section{Knowledge management}

According to Davenport \& Prusak (1998), knowledge is the information combined with experience, context interpretation and reflection. Nonaka \& Takeuchi (1995) make a difference between explicit knowledge (that which could be transmitted through words, mathematical formulas and symbols) and tacit (product of experience, difficult to communicate and share with others because it's personal). Choi \& Lee (2002) define knowledge management as the ability of all those working in the company for moving knowledge resources and complementing them with other resources and organizational capabilities, for which they divide knowledge management in four sub-processes: knowledge (1) creation; (2) manifestation; (3) use and (4) transfer. For Barroso (2011) they are knowledge (1) acquisition; (2) generation; (3) use and (4) transfer. Organizations with better knowledge management perform better in their markets, but it is necessary to have willing and able to learn workers...this is, people able to acquire, generate, use and transfer knowledge in an effective way, able and willing to work in teams and implement a good leadership style.

\section{Case study method and case studies}

We must distinguish the "case study method" from "case studies". The first, according to Yin (2014), is "the empirical enquiry that investigates a contemporary phenomenon (the case) in depth 
and within its real word context" (p. 16), and must be based on rigor, validity and reliability. It's a research method in which the analysis technique consists of matching empirically observed events to theoretically predicted events. This method:

a) Focuses on a contemporary phenomenon within its real life context. It is suitable for studying complex social phenomena, especially when boundaries are not clearly evident;

b) Includes many variables of interest, multiple sources of evidence, and theoretical propositions;

c) They could be exploratory, explanatory or descriptive in type;

d) The designs could be simple or include multiple cases, and

e) Could use qualitative, quantitative or both methods.

For Giménez (2012), social research could be variable oriented (Large-N research) referring to generalization studies, or case oriented (small-N research), looking for deeper understanding of a research unit. Case study method instruments must be valid (to search what they are supposed to) although the results are not generalized (to use the resulting information in other contexts). However, the method could be replicated in other contexts with the corresponding changes.

On the other hand, according to the Carnegie Mellon University Eberly Center [CMUEC] (2015), case studies are stories which show realistic, complex and contextually rich situations, often involving a dilemma, conflict or problem to be analyzed and negotiated. For The University of New South Wales [UNSW] (2013), a case study is an account of an activity, event or problem that contains a real or hypothetical situation and includes the complexities the student would find in the workplace. I define case studies as logical constructions of facts, real or fictitious, but based on theory or in real contexts, for fostering learning in the participant. The objective of a case study is creating an opportunity for a learning to learn experience to occur, in both the professor or instructor, and the participants or students. Another name I would suggest calling case studies, for avoiding confusions with the case study method, is "training cases". Then, the case study method is a methodology of research, and case studies (or training cases) are logical constructions, based on real or theoretical facts, for fostering learning in class, the enterprise or in any other context. 
A good case keeps the class discussion focused and grounded upon some facts that must be faced in real life situations. For Ellet (2007), case studies are used to help students see the complexities of real life and the influence of the decisions made. They have been used in teaching medicine, and law and business. Nonetheless, they could be helpful in any field or discipline. One of the advantages of using cases is that "they bridge the gap between theory and practice and between the academy and the workplace" (Barkley, Cross, \& Major, 2005, p.182, quoted by CMUEC, 2015). They also give students the opportunity for identifying the parameters of a problem, recognizing and articulating positions, designing and evaluating courses of action and discussing different points of view. For Vega (2009), the benefits of working with case studies are skill development, content application and personal growth.

Case studies could be different according to the topic, situation or the teachers' goals (Ellet, 2007). They could be short (a few paragraphs) or long (e.g. 20+ pages, but no more than 50), used in lecture-based or discussion-based classes, written with all the details from actual people and circumstances or simply realistic, provide all the relevant data students need to discuss and resolve the central issue or just part of it, requiring students to identify and possibly fill in (via outside research), the missing information. For UNSW (2013), an issue to be attached is that the case must be believable for the reader. Whatever the source, an effective case study is one that, according to Davis (1993) and quoted by CMUEC (2015):

- tells a "real" and engaging story

- raises a thought-provoking issue

- has elements of conflict

- promotes empathy with the central characters

- lacks an obvious or clear-cut right answer (otherwise, it would be just an exercise as in math or accounting)

- encourages students to think and take a position

- portrays actors in moments of decision

- provides plenty of data about character, location, context, actions

- is relatively concise 
In a case study class, students and teachers depend on each other. The art of a teacher for using case studies is asking the correct questions in the correct moments, giving feedback and keeping a discussion to open the meaning of the case. Even when case discussions are full of facts and information, they are not oriented to a unique truth. The best case is that without solution, but that enhances discussion and learning.

The purpose of a case is representing reality to converge in one situation, regardless of the differences in opinions or if information is scarce or excessive (Ellet, 2007; Giménez, 2012). A case without a relevant problem to solve has no educational value, and that's why it must have these three features:

1) A relevant topic, problem or affair related to business. Avoid "noise" or everything that could be confusing.

2) Enough information for solving the case. Conclusions must be based on that information.

3) It must not have pre-established conclusions.

A well written case must meet the following points:

1) Build conclusions based on the information given in the text.

2) Separate all irrelevant or low value information.

3) Provide the missing information through inferences.

4) Associate evidence from different parts of the case and integrate them in a conclusion.

A case is a text which rejects to be self-explained. How does one build meaning from it? To analyze a case, it is necessary to identify and understand important aspects of a situation and what they mean. The students must dedicate more time thinking about the case, than reading it (Ellet, 2007). In analyzing cases, there are three kinds of situations: (1) problems; (2) decisions and (3) evaluations:

Problems. A problem is a situation in which something important has happened, but we do not know why it happened. Problem analysis starts with a definition of 
it. It is necessary to accept a problem and to solve it. Then, explain the problem joining the result or the performance to the root cause. Relevant tools and special methods from business disciplines such as Organizational Behavior or Operations Analysis are required.

Decisions. The most important is setting a criterion. A rational decision can not be made without the correct criterion. The objective is to determine a decision that creates the best adjustment between the evidence and the indicators. As there is not only one correct objective, the best will be the one which generates more benefits than alternatives and with less problems.

Evaluations. They are judgments about the value or the effectiveness of a performance, act or result. The evaluation unit could be an individual, a group, a department, an organization, a country or even a global region.

The key process is active reading. Asking questions give a meaning for reading, as well as direct and focus the study on the important aspects of a situation. The following concepts contribute to an active reading:

a) Analyze the objective.

b) Understand the leading role's point of view and place yourself in his shoes.

c) Finding a hypothesis, which is a preliminary explanation of a set of facts that could be tested in a future research. The advantage is that the case could be tested against the evidence. It must be feasible to be tested in real life.

\section{Case study classification}

According to its structure, there are two kinds of cases (Ellet, 2007):

a) Without and ending: the students have to deduct the end.

b) With an ending: the students judge if the solution is correct, according to what was studied in class. 
Vega (2009) identifies two kinds of cases: (1) teaching cases, which present a problem for students to solve, with the intention of generating class discussion and individual or group analysis, and (2) research cases, written for developing and testing theory and extending concepts, without leaving the reader a problem to solve. In my experience, cases could be written incorporating elements of both kinds.

\section{Traditional presentation of a case study}

Ellet (2007) suggests that case studies must be presented to students in the following way:

1) Situation (5 minutes). It is recommended to read the first and last section of the case to be able to understand it. The beginning and the end of a case could offer a partial or complete description of the facts. Then, the case must be taken apart to verify what we learned from it. Is the situation a problem, a decision or an evaluation? Which is the focus? Is there enough information or is it scarce?

2) Questions (5 minutes). Once you know the situation, it is necessary to ask what you need to know about the situation. If it's a problem, we have to know who the subject is (the manager, a firm, a country), the problem, the meaning of the problem for the subject, who is responsible for the problem and what he needs to know for doing something regarding this; if it's a decision, we need to check what our options are in making this decision, if there is a weak one, what is at stake in the decision and which are the possible indicators, as well as if the most important criteria are explicit in the case. If it's an evaluation we need to know who or what is being evaluated, who is responsible for such evaluations, the criteria to evaluate and if the case criteria are widely discussed.

3) Hypothesis (15 minutes). Problem: be sure you know the problem to be diagnosed. Look for suggested causes and think in the concept frames that seem most appropriate. Analyze according to the most important detected cause. If there's abundant quantitative evidence, find the most important causes. Decide if the leading role is a potential problem, and if so, determine to which extent this contributes to the problem. Decision: check the criteria. Which one do you trust? Check options. If there is too much quantitative information, decide which criterion 
is the most relevant. Look for the highest value evidence. Evaluation: check criteria and the terms to be used and start using the criterion you trust most.

4) Test and action (40 minutes). What evidence can you utilize to justify the hypothesis?

5) Alternatives (15 minutes). Problem: Could it be identified? What is the weakest part of a hypothesis? Decision: What is the main inconvenience in the recommended decision? How do you handle an inconvenience? What is the strongest evidence against the recommendation? Evaluation: Have you been objective and thorough in evaluating the findings? How could evaluation be different?

\section{Case study solving}

For Ellet (2007), the objective of case studies used in class is achieving congruent conclusions with the reality of the case, keeping in mind that there is uncertainty. Due to this, students must be able to communicate their ideas in an effective manner. As Aceves \& Barroso (2016) mention, in career development, there must be special attention to socioemotional competencies such as communication, leadership, teamwork and conflict solving. Technical competencies (knowledge and skills) are not enough for professional success. Case studies could help students acquire the socioemotional competencies they will need for career success.

Case solving could be in groups of up to five members (Vega, 2009), enhancing discussion in class and preparing formal presentations. The participant's role is advancing discussion and contributing to collective understanding of the case (Ellet, 2007). There must be emphasis in case analysis, discussion, how to write cases and then the implementation of them. The usual procedure followed for case studies in education is the following:

1) Ask students to write some starting questions before the case is presented. Divide them in groups of up to five students. Do not allow groups of just one student.

2) Let them discuss those questions in small groups and share their results with the larger group (the class).

3) Have them read the case in small groups (this could be done at home as a homework assignment).

4) Give them the questions or assign the activities to be done.

No 19, Vol. 9 (2), 2017. ISSN 2007 - 0705, pp.: 568 - 594 
5) They work in small groups and then present their results to the whole class.

6) You give them feedback and present the epilogue (the final part of the case, where a solution is given by the case designer, but the idea is to enhance further discussion). Students discuss the epilogue.

7) You assign homework and further reading related to the case.

8) One case could be used in more than one course, depending on the topics to be discussed.

\section{Case studying writing}

In classes, teachers could use the Socratic Method leading students to a discussion through a “question river" (Elliot, 2007). These are some questions that could be asked:

1) Does the change described have worth? If the answer is affirmative, why did it fail when it was implemented? Could it have been successfully implemented?

2) How attractive was the industry described in the case? Are some segments more attractive than others? If this is so, then why? Identify, analyze and evaluate the company strategy.

3) What are the pros and cons? What is the impact?

The purpose of case studies is getting to congruent conclusions with the reality of the case, taking in mind their paths and uncertainty (Ellet, 2007). Secondly, students must be able to communicate their thoughts in an effective way (Aceves \& Barroso, 2016).

In Social Science, conclusions have little meaning unless they are shared with others. The implementation of case studies is for setting and sharing opinions and learning from differences and similarities. The results could be shared and discussed with the complete classroom or in small groups, orally or through a formal presentation. The role of every participant must be to discuss and contribute to the collective understanding of the case (Elliot, 2007). That's why it is necessary to (1) analyze the case, (2) discuss it, and (3) learn how to write cases. For Vega (2009), writing cases help students learn about a topic, business units and the people who run them, as well as get involved in the analysis and improve the socioemotional competencies, as Aceves \& Barroso (2016) mentioned. 


\section{Method}

There were two parts: Part 1 (Students) and Part 2 (Auditors). For part 1, the focus was quantitative (Hernandez, Fernandez \& Baptista, 2014; Creswell, 2003), descriptive and using a preexperimental design because the results in the study will be compared with the same participants before and after the intervention (test-retest). As every group of students was different and working in a different context, it was not possible to compare them, so the selected design was the preexperimental, which means there is not a control group. For Auditors (part 2), the study was exploratory with a non-experimental (ex post facto) design, in a qualitative focus, using the interview as the information gathering technique.

\section{Participants}

\section{Part 1: Students}

From a total amount of about 250 students working in the GADs in the three cities, there were seventy professional practice students participating (it is an internship, as mentioned before), divided into fourteen groups of five individuals in each. About their major, 54.3\% were studying Accounting, 27.1\% Business Administration, 10\% Economics and the remaining 8.6\% were studying other majors such as: (Engineering, Architecture, and Anthropology). There gender was $64.3 \%$ of them were men. The average age was 21 years old (standard deviation $[\mathrm{SD}]=2.1$ years), and $83 \%$ were from public higher education institutions. All of these students were under the supervision of the Auditors studying the Master in Auditing degree at the Anahuac Mayab University campuses in the three cities mentioned before. This institution is private, with 32 years in the Southeast of Mexico and belongs to the Anahuac University Net, with 52 years in the country. The students were distributed as follows:

Chetumal: eight groups of five Auditors worked with eight groups of five professional practice students, which means that every group of five Auditors taught a group of five professional practice students working at the GAD.

Merida and Campeche: in each city, three groups of five Auditors worked with three groups of five professional practice students, so each group of Auditors taught one group of five undergraduate students. 
The results were analyzed considering all the participating students, who are the subjects in this study, as an analysis unit. In a preliminary study, there was no significant difference among the undergraduate students regarding age, background, school level and socioeconomic level. It is important to say that the researcher used the same methodology with the Auditors in the three cities as part of their Master's degree studies.

\section{Part 2: Auditors}

One Auditor representing each group answered the interview guide, so there were fourteen participants (nine of them men). The average age was 45 years old ( $\mathrm{SD}=6.2$ years). Eight were from Chetumal, three from Merida and three from Campeche.

\section{Instruments}

\section{Part 1: Questionnaire for professional practice students}

The instrument used as a pretest and posttest was a questionnaire designed by the author of this research. It included the following items: (1) Motivation for learning; (2) Interest in case studies; (3) Self confidence at using case studies; (4) Satisfaction with students' learning; (5) Feeling of being prepared for a career, and (6) Usefulness of case study for preparing students for career success. This was based in the studies included in the literature review. There was an open answer section for writing comments about the experience. Content validity was verified through face validity (Hernández et al., 2014), for which three experts reviewed the case study and approved it. Reliability was using Cronbach's alfa coefficient, resulting 0.81 after applying the test to fifteen participating students $(21.4 \%$ of the sample). It was implemented by the Auditors, and the results were reported to the researcher.

\section{Part 2: Interview guide for Auditors}

It was prepared for the Auditors to give their perception of their students' performance. It asked if those students learned faster through case study solving, designing and implementing, rather than using those traditional class methods. It also asked if they considered their students were satisfied with the experience. It was also validated through three experts' judgement (Hernandez et al., 2014) and implemented by the researcher.

No 19, Vol. 9 (2), 2017. ISSN 2007 - 0705, pp.: 568 - 594 


\section{Procedure}

The procedure to be tested for this experience was the following in each of the three Mexican cities, enhancing a correct learning environment as Brent (1996) and Honebein (1996) suggest. In this case, the leader was the researcher (the author of this document), but in the future it could be a professor or a training manager.

1) Auditors studying the Master in Auditing participated in the Case Study course, which is part of their study program.

2) As part of their final work, those Auditors designed (in groups) a case study about a topic for teaching their new staff, who were GAD students in professional practices.

3) Pretest implementation to the students in the GAD (Part 1 instrument).

4) Auditors taught the GAD students how to solve the cases using the case they designed according to the methodology described in the literature review.

5) GAD students, in teams of five and grouped by proceeding institution and under the Auditors' team guide, prepared a case for implementing at their schools in a classroom, with the corresponding professor's permission, so the case designed must have been in accordance to that class. An Auditing class was preferable, but it could have been any other course. That professor and his students were invited to give feedback to the case designers regarding the case and the implementation.

6) Posttest implementation to the students in the GAD (Part 1 instrument).

7) Auditors reported (Interview guide for Auditors):

a) Their own team learning through cases

b) The students' performance at implementing a case at school

c) The students' satisfaction with the experience as a career preparation

8) The GAD students prepared a twenty-minute PowerPoint presentation, including a five to eight-minute video, to show how they followed the procedure, the results and their learning. This presentation is at the GAD office.

9) The students received feedback from the Auditors and the researcher and set future action plans.

No 19, Vol. 9 (2), 2017. ISSN 2007 - 0705, pp.: 568 - 594 
Elements from the case study method (Yin, 2014) were considered for designing the cases studies, focusing on contemporary phenomenon within real life context and using both qualitative and quantitative methods for finding a solution. Following Elet (2007), the extension was twenty pages but no more than fifty, using an accepted style guide (preferably APA), analyzing problems, decisions or evaluations. The cases designed by Auditors to students and from students to their classmates could be teaching or research cases (Vega, 2009), and in both kinds they could be with an ending or without one (Ellet, 2007). The way cases were presented to their respective audiences was the one mentioned in the literature review.

Quantitative data was analyzed using SPSS (Statistical Package for the Social Sciences) and Excel utilities. For numerical results interpretation, the following scale was used:

Table 1. Scale for result interpretation.

\begin{tabular}{cc}
\hline Interpretation & Result \\
\hline Totally agree & 4.6 to 5 \\
Agree & 3.6 to 4.5 \\
More or less agree & 2.6 to 3.5 \\
Disagree & 1.6 to 2.5 \\
Totally disagree & 1 to 1.5 \\
\hline
\end{tabular}

Qualitative answers were grouped together by similarity in key ideas, and organized in defined categories. For grading the GADs students, three aspects were considered: (1) Structure: to which extent the students followed the procedure for this study (point 5 of the procedure); (2) Content: that the case is based on real life aspects or in theory (point 5 of the procedure), and (3) the results and conclusions presented (point 8 of the procedure). A scale, used as a simple rubric, was used:

Table 2. Scale for assigning grades.

\section{Result} Grade

Outstanding! Complete and in order. Total clarity. 10

Very well! Minor mistakes, but complete, clear and in order.

Well. Evident mistakes, but complete, clear and in order

More or less. Minor mistakes, but incomplete, unclear or some disorder 
Minimum acceptable. Evident mistakes, incomplete, unclear or in disorder $\quad 6$

Not acceptable. Significant mistakes, incomplete, unclear or in disorder. 5

Missing section

\section{Results}

\section{Students' pretest and posttest}

The difference was significant $(\mathrm{t}=-5.165, \mathrm{p}=0.004<0.05)$, which means there was an improvement in the results after the experience than before, according to the pretest and posttest. They totally agree (4.6) that they were motivated by this experience, compared to when they started. They are more interested in case studies (4.7, totally agree) and feel more confident for solving them (4.3, Agree). They are more satisfied with the learning (4.6, totally agree) and feel they are much better prepared for career success if they use case studies (4.4, Agree), compared to when they started this experience, in which they more or less agreed (2.6). As they had solved case studies in the past, they agreed (4.2) that this is a good strategy for learning, but after the experience they totally agreed (4.8) about the value of case studies for career success. In the pretest, the mean was 3.62 (Agree, $\mathrm{SD}=0.601$ ), but at the end they the result was enhanced, achieving 4.57 (Totally agree, $\mathrm{SD}=0.186)$.

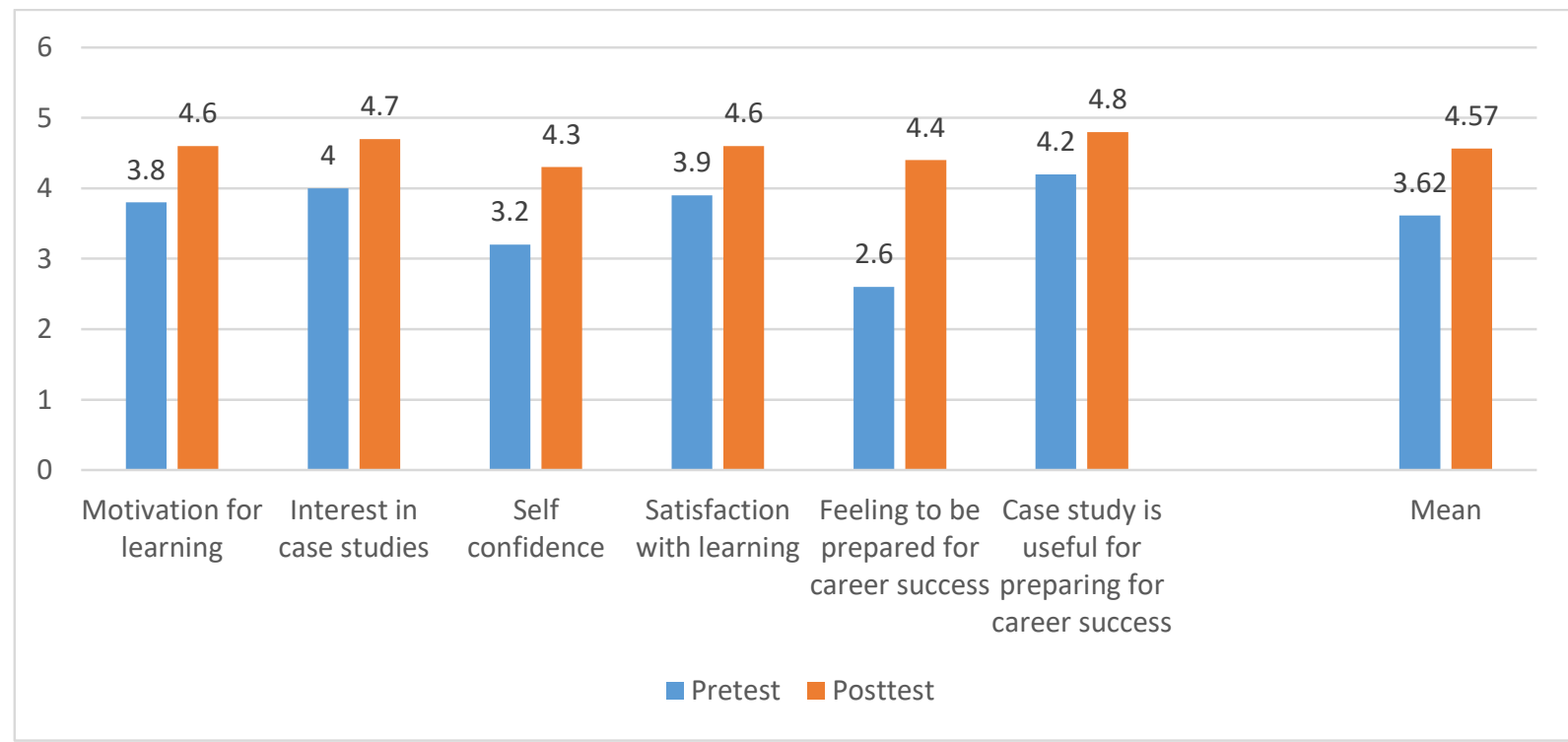

Figure 1. Pretest vs. posttest means comparison. 
In the open answer section, the students mentioned the following statements (\% of total mentions):

1) They were surprised to see that it was possible to teach and learn at the same time, especially when they were mostly use to the traditional teacher-student method $(67 \%)$ in a classroom.

2) They were highly motivated to continue learning because of this experience. (53\%)

3) They liked the exercise because it incorporated leadership skills, teamwork, speaking in public and teaching helping others to learn. (48\%)

4) They enjoyed being their classmates' teachers when implemented the cases at their schools. $(42 \%)$

5) They learned topics in an interesting and dynamic environment. (40\%)

6) They felt creative and participative. (38\%)

7) They are willing to use this strategy when they work professionally. (35\%)

\section{Auditors interview guide}

The Auditors agreed that the students at the GADs were interested and challenged in the cases they had to solve, but they were more interested in how to make a good case to test at their schools. There were many hours of research and teamwork for having good cases, enhancing discussion and creativity in the process. The learning was significant and knowledge assimilation was faster, more motivating and fun than using the traditional teacher-student format. The cases were about Governmental Auditing, so they included topics of Accounting, Finance, Cost Accounting, Budget Control, Fiscal Issues, Economics and Supervision of public infrastructure work. It is important to say that Auditors also learned helping their GAD students to learn, so when using case studies, authors and participants have a learning experience not only at designing a case, but at the moment of implementing it. Besides, the reactions and group behavior when participants solved the cases are sources of new learning for the author.

\section{Discussion}

Both, the Auditors and the participating students, agreed that they could be better prepared using case studies to practice and incorporate new learning, which could be useful for building socio-

No 19, Vol. 9 (2), 2017. ISSN 2007 - 0705, pp.: 568 - 594 
emotional competencies to improve performance at work, as Aceves and Barroso (2016) suggest. This is consistent with the benefits of constructivism (Peters, 2012) and the importance of case studies for a better learning (Ellet, 2007; Vega, 2009). Although case studies were not new for Auditors and most students, its use proven to be successful in class, challenging and motivating, inviting students to explore, discover, experiment and learn, transforming tacit knowledge into explicit (Nonaka \& Takeuchi, 1995). Case studies help students see the complexities of real life (CEMUEC, 2015) and link theory with practice in a believable way (Ellet, 2007; UNSW, 2013). Case studies are a good strategy for increasing intangible assets, as Kaplan \& Norton (1996) suggest.

In this experience, students at the GADs learned (or remembered) how to solve cases, but also discovered how to design one and implement others, which was a new task for them. It was expected that some Auditors and students reject and show some resistance to work with cases, but it did not happen. They were confident and happy working with cases. However, what was not expected -but happened- is the great motivation and the friendly competition among the groups of students, so part of the success at solving cases rely on the group influence and the orientation to challenge. Social pressure can influence individual behavior, and in this case, performance was positive. This was possible because of the favorable learning environment created (Brent, 1996; Honebein, 1996, \& Peters, 2012).

Students learned and were satisfied with the results of this experience. They felt challenged and their creative and critical thinking were improved, as Barroso (2010) suggests in his research. Cases are great opportunities for explicit knowledge, practice, getting more experience, discovering values and making social nets, as Sveiby (2001) reported. They followed the knowledge management process suggested by Barroso (2011): knowledge acquisition, generation, usage and transfer. Better knowledge management creates value for any organization. Another benefit observed in the intervention is that socio-emotional competencies were built in the experience, so case studies are good at enhancing them (Vega, 2009). Those competencies will be important in the future, as Aceves \& Barroso (2016) mentioned. Then, if solving cases is a good way for learning, writing a case and having someone solve it goes beyond, making learning more significant, faster and enjoyable for the writer-implementer, which indicates that the procedure presented in this research was effective for such purpose. 
Although the focus in this research was based on the GAD students, it could be said that the same effect occurred with Auditors because they learned more preparing and implementing cases than just solving them. There was a double learning: they learned when they taught GAD students to solve-design-implement cases, and those students experienced the same with their fellow classmates at their universities. So, more than solving, it is learning to learn, using that learning in real contexts and transferring the knowledge to others. This is possible when the person is capable and willing to learn, for which a correct labor environment must prevail.

\section{Conclusions}

This experience is important because besides learning through cases, students also improved team work competencies. They followed and learned from their Auditors and appropriated that experience for use at school in a nice and challenging environment, as Honebein (1996) suggests. However, the real challenge for students was to be able to write and implement those cases. This way they got connected to real work situations (Giménez, 2012; Ellet, 2007) and were motivated to solve problems (UNSU, 2013). Then, it could be said that the procedure presented was effective for training students to write and implement case studies and improve their learning experiences, compared to traditional methods, measured in terms of results and satisfaction. They were more motivated, interested in the situations, and more confident and satisfied with the experience. For learning how to learn, the environment must be enhancing and the task must be meaningful, important, challenging and enjoyable.

The benefit was evident for Auditors and GAD students. Solving case studies was good, but writing, implementing them and receiving positive feedback from participants was an outstanding rewarding experience, which motivated those students to work more enthusiastically. It was an ability they did not know they could develop and realized it is a good way to be prepared for what they will face in the labor market. In conclusion, writing and implementing cases in real job contexts is significantly effective for helping students to learn, improve learning experiences, adapt to their labor environment faster and be better prepared for career success.

\section{Acknowledgements}

I would like to thank the Accreditation Council for Business Schools and Programs (ACBSP) and the Anahuac Mayab University for the opportunity to present this experience at the Region 9 (Latin

No 19, Vol. 9 (2), 2017. ISSN 2007 - 0705, pp.: 568 - 594 
America) International Congress and Accreditation Forum in Cancun, Q. Roo, Mexico, in December 2016, in which it was awarded with the Best of Regions Second Place. Also, my acknowledgement to Mrs. Angela Garland de Canché for her kind attention at reviewing the document.

\section{References}

Aceves, M. A. \& Barroso, F. (2016), “Competencias socioemocionales en las prácticas profesionales. Un estudio en la industria hotelera" [Socioemotional Skills in Business Practice. A Study in the Hotel Industry], in Educación y Ciencia, núm. 45, vol. 5, pp. 3449.

Barroso, F. (2010), Factores a considerar para desarrollar la creatividad en las empresas. Un estudio en 70 empresas en la ciudad de Mérida, Yucatán [Factors to consider for developing creativity in enterprises]. Proceedings of the XV International Congress of Accounting, Administration and Informatics. School of Accounting and Administration, National Autonomous University of Mexico.

Barroso, F. (2011), Gestión del conocimiento en empresas y organizaciones sociales productivas exitosas en el estado de Yucatán [Knowledge management in enterprises and social productive organizations in the state of Yucatan]. Proceedings of the XVI International Congress of Accounting, Administration and Informatics. School of Accounting and Administration, National Autonomous University of Mexico.

Barroso, F. y Córdova, M. (2013), Gestión del conocimiento y desempeño organizacional en micro y pequeñas empresas de poblaciones del interior del estado de Yucatán. Avance de investigación [Knowledge management and organizational development in micro and small enterprises in towns in the State of Yucatan. Research advances]. Proceedings of the XVIII International Congress of Accounting, Administration and Informatics. School of Accounting and Administration, National Autonomous University of Mexico.

Brent, W. G. (1996), “What is a constructivist learning environment?” In W.G. Brent (Ed.), Constructivist learning environments. Case studies in instructional design, pp. 1-5. Englewood Cliffs, NJ, Educational Technology Publications. 
Preparing undergraduate students for career success through case study writing and implementation in real job contexts

Carnegie Mellon University Eberly Center (2015), "Case studies". Available at https://www.cmu.edu/teaching/designteach/teach/instructionalstrategies/casestudies.html (retrieved on December 10th, 2016)

Choi, B. \& Lee, H. (2002), "Knowledge management strategy and its link to knowledge creation process", in Expert Systems with Applications, num. 23, pp. 173-187.

Creswell, J. (2003), Research design. Qualitative, quantitative and mixed methods approaches. U.S.A., Sage Publications.

Davenport, T.H. \& Prusak, L. (1998), Working knowledge. How organizations manage what they know, U.S.A., Harvard Business School Press.

Ellet, W. (2007), The case study handbook. How to read, discuss and write persuasively about cases, U.S.A., Harvard Business School Press

Flavell, J.H. (1978), "Metacognitive development". In J.M. Scandura \& C.J. Brainerd (Eds.). Structural process models of complex human behavior, Holland, Sifthoff y Noordhoff.

Giménez, G. (2012). El problema de la generalización de los estudios de caso [The problem of generalization in case studies], in Cultura y Representaciones Sociales, núm. 13, vol. 7, pp. 40-62.

Kaplan, R. \& Norton, D. (1996), The Balanced Scorecard: Translating strategy into action, U.S.A., Harvard Business School Press.

Hernández, R.; Fernández, L. \& Baptista, P. (2014), Metodología de la investigación [Methodology of Research], 6th. Ed, México, McGraw Hill.

Honebein, P. C. (1996), "Seven goals for the design of constructivist learning environments". In W.G. Brent (Ed.), Constructivist learning environments. Case studies in instructional design, pp. 11-24. Englewood Cliffs, NJ, Educational Technology Publications.

Nonaka \& Takeuchi, H. (1995), "La organización creadora de conocimiento" [The knowledge creating organization]. New York, Oxford University Press.

Peters, R. G. (2012), "Differences Between Traditional and Progressive Education". Wingra School. Available at http://www.wingraschool.org/who/progressive.htm (retrieved on November $\left.27^{\text {th }}, 2016\right)$.

Robbins, S. y Judge, T. (2013), Comportamiento organizacional [Organizational Behavior] (15th. Ed.), México, Pearson. 
Robinson, K. (2010), Changing Paradigms [Video]. Available at https://www.youtube.com/watch?v=drADqeSSnFc (retrieved on September $30^{\text {th }}$, 2016).

Sveivy, E. K. (2001), Towards a knowledge-based theory of the firm, in http://www.sveiby.com/articles/knowledgetheoryoffirm.htm (retrieved on January 12th, 2013).

The University of New South Wales. (2013), "What is a case study?" in https://student.unsw.edu.au/what-case-study

Vega, G. (2009). "The Undergraduate Case Research Study Model”, in Journal of Management Education, num. X, Vol. XX, pp. 1-31.

Yin, R. K. (2014). Case Study Research: Design and Methods ( $5^{\text {th }}$. Ed). U.S.A., Sage Publications. 